\title{
Fleeing from the Global Compact for Migration: A missed opportunity for Italy
}

\author{
Chiara Scissa ${ }^{1}$
}

\begin{abstract}
This article examines the reasons that in December 2018 led both the Italian Parliament and Government to refrain from the Global Compact for Safe, Orderly and Regular Migration, which first Italy promoted as a way to revitalise the European Union's solidarity and coordination, while lessening the uneven burden of migratory inflows into the country. Although it has been argued that 'the opposition to the Compact has propagandistic objectives, that cannot be negotiated away' (Gatti, 2018, p. 1) this article aims to demonstrate the wide socio-economic and political benefits that the Global Compact will bring to Italy if adopted, as well as the gains that an instrument of international migration governance will bring to national migration policy. This contribution also highlights the opportunities that the Global Compact offers a truly common European approach to migration.
\end{abstract}

Keywords: Global Compact for Migration; Italy; migration governance; European Union; nationalism.

\section{Introduction}

This article ${ }^{2}$ explores a recent attempt to bridge the gap between migration governance ${ }^{3}$ and migration policy ${ }^{4}$ by means of a hoped-for 'universal' system of international cooperation - the Global Compact for Safe, Orderly, and Regular Migration (hereinafter GCM or Global Compact). In particular, this contribution examines the reasons that in December 2018 led both the Italian Parliament and Government to refrain from the Global Compact, which Italy first had promoted as a way to revitalise the European Union's solidarity and coordination, while lessening the uneven burden of migratory inflows into the country.

Although it has been argued that 'the opposition to the Compact has propagandistic objectives, that cannot be negotiated away' (Gatti, p. 1), this paper aims to demonstrate the wide benefits that the GCM will bring to Italy if adopted, in other terms, the gains that an instrument of international migration governance will bring to national migration policy. This is believed to be the first thorough analysis of the political debate around the Global Compact in the case of Italy from a

1 Chiara Scissa, Ph.D student, Sant'Anna School of Advanced Studies, DIRPOLIS Institute, Pisa, Italy. E-mail: chiara.scissa@santannapisa.it.

${ }^{2}$ My deepest gratitude to Professor Marco Borraccetti for his constant support and wise advice, and to PhD Susanna Villani for her bibliographical suggestions

${ }^{3}$ Betts defines global migration governance as 'a range of norms, rules, principles, decision-making procedures that exists over and above the level of a single nation-state' (Betts, 2010). See also IOM 2019 Glossary on Migration, available at https://publications.iom.int/system/files/pdf/iml_34_glossary.pdf

${ }^{4}$ Bjerre et al. define migration policy as 'a government's statements of what it intends to do or not do (including laws, regulations, decisions or orders) in regards to the selection, admission, settlement and deportation of foreign citizens residing in the country' (Bjerre, Helbling, Römer, \& Zobel, 2014) 
political and legal perspective. The first section draws up a list of major concerns expressed by right-wing parties during Parliamentary debates, prompting them to vote against the Global Compact, ranging from the 'annihilation of national borders, sovereignty and cultures' ${ }^{25}$ to the perceived obligation to guarantee free and unconditional entry. The second section challenges these allegations, echoed also by other majority groups, by directly recalling not only principles of customary law and human rights law that Italy must comply with, but also the relevant law enforcement promoted by the European Court of Human Rights (ECtHR) and national tribunals, thus demonstrating the legal groundlessness of most of the arguments used to discredit the Global Compact. By deeply analysing institutional statistics and data as well as by relying on the existing literature on the matter, the second section also produces evidence of adequate migration governance solutions enshrined in the GCM. The specific socio-economic, fiscal, and demographic opportunities that the Global Compact offers to Italy and its whole community will be at the core of the third and last section.

This paper also finds that the Global Compact would add value to the EU migration governance with significantly positive national impacts. Among others, the collective effort to achieve Objective $4^{6}$ would indeed allow the first two hierarchical criteria ${ }^{7}$ of the Dublin III Regulation to take place, with a double immediate effect: 1) when these criteria apply to the case, designated EU countries other than the first entered should thus take on their responsibilities for the evaluation of the international protection request; 2) a subsequent, initial redistribution of migrants first arriving in Italy would finally start. Similarly, if Objective $5^{8}$ is seriously implemented, EU institutions and Member States should then adopt and promote the use of humanitarian visas to regularly and safely travel to Europe for international protection purposes. Here again, the Italian burden would be relieved and thousands of lives would be spared.

\section{On the Global Compact: merits and weaknesses of a soft law instrument}

The Global Compact for Safe, Orderly and Regular Migration is the first-ever UN global arrangement that recognises that solid international cooperation is needed to maximise the overall benefits of migration (Rita, 2019), while minimising its risks for individuals and communities in vulnerability. This two-year negotiated agreement relies upon principles of State sovereignty, responsibility-sharing, the rule of law, and human rights and sets out 23 Objectives to make migration work for all.

Scholars' opinions on the merits of the Global Compact widely differ. Frequently, the reason for supporting its adoption or its rejection ${ }^{9}$ lies in its non-binding nature. Accordingly, giving human

\footnotetext{
${ }^{5}$ Quotation taken from the speech of Giorgia Meloni (Italian Deputy and leader of the right-wing party Fratelli d'Italia). See Italian Chamber of Deputies, 102nd Session - Debate on the adoption of the Global Compact for Migration, 18 December 2018, 9.30 AM

${ }^{6}$ Objective 4: Ensure that all migrants have proof of legal identity and adequate documentation, Global Compact for Safe, Orderly, and Regular Migration final draft

${ }^{7}$ Chapter III, Criteria for determining the Member State responsible, Articles 9-10 (Family members) and Article 12 (Issue of residence documents or visas). See Regulation (EU) No 604/2013 of the European Parliament and of the Council of 26 June 2013 establishing the criteria and mechanisms for determining the Member State responsible for examining an application for international protection lodged in one of the Member States by a third-country national or a stateless person (recast)

${ }^{8}$ Objective 5: Enhance availability and flexibility of pathways for regular migration, Global Compact for Safe, Orderly, and Regular Migration final draft

${ }^{9}$ (Nyers, 2019); (Chimni, 2018); (Carling, 2019); (Newland, 2018)
} 
rights-related arrangements some legal force may be, understandably, preferable to giving them no legal status (Roberts, 2001, p. 790).

Nevertheless, soft law instruments are progressively characterising contemporary international lawmaking, in preference to the conclusion of new treaties ${ }^{10}$. A. Boyle and C. Chinkin define soft law instruments as ' $a$ variety of non-legally binding instruments [...], which encompasses interstate conference declarations, interpretive guidance adopted by human rights treaty bodies, nontreaty inter-state agreements, and common international standards adopted by transnational networks of regulatory bodies' (Boyle \& Chinkin, 2007). I. Wuerth's analysis on customs and soft law showed that, despite the fact that the former is binding and the latter is not, they have several features in common. According to the author, akin to soft law, customs do not need to be entirely in line with States' consent or to be nationally ratified, they may have lower contracting costs, and they are flexible in content (Helfer \& Wuerth, p. 2). In light of these similarities, Wuerth's study concluded that 'custom can be understood as existing on a continuum between treaties and soft law' (Helfer \& Wuerth, p. 4)

Moreover, soft law instruments might promote the development of customary laws, despite their lack of binding force, therefore generating new obligations for States. As recalled by $\mathrm{M}$. Villegas Ergueta, Article 38 of the Statute of the International Court of Justice (ICJ) indicates two grounding elements for the establishment of customary laws: 1) a general, constant, and uniform practice; and 2) a recognition that such practice amounts to law, commonly known as opinio iuris (Villegas Ergueta, 2015, p. 189). Remarkably, L. Hannikainen noted that soft law instruments too can reflect general consensus (Hannikainen, 2006) and, according to the author, the affirmative voting of resolutions of international organs, typical examples of soft law, constitute not only relevant State practice but also opinio iuris of States as well as of the international organisations involved. Villegas Ergueta's study on soft law indicates that the ICJ interpreted several resolutions of the UN General Assembly as having a normative value that, according to her, may confirm the emerging existence or the establishment of opinio iuris (Villegas Ergueta, 2015, p. 195). The author stressed the particular case of human rights law, assessing that 'These fields share as a particular feature: strong opinio iuris, enshrinement in international conventions, and they are characterised by inconsistent state practice. In that sense, for instance, customary law that prohibits genocide remains intact, notwithstanding the multitude of examples of non-compliance, because opinio iuris regarding the duty of compliance continues to exist'. Therefore, she concluded that 'Although, one may say that if a State consistently votes for such resolutions, it cannot rely on the assumption that this affirmative expression has no legal consequences' (Villegas Ergueta, 2015, p. 196).

In evaluating the innovative content of the GCM, D. Vitiello considered both Global Compacts as 'reinforced"11 soft law instruments, given their formal adoption respectively by means of an intergovernmental conference and the General Assembly. Her study proceeded with an analysis of the 2016 New York Declaration that, pursuant to its preambular paragraph no. $2^{12}$, could be seen as the international community's common response to large movements of refugees and migrants and,

\footnotetext{
${ }^{10}$ (Helfer \& Wuerth, 2016, p. 563). See also, (Helfer \& Wuerth, Working paper: Custom in the Age of Soft Law )

11 (Vitiello, 2018, p. 3). Personal translation.

${ }^{12}$ New York Declaration on Refugees and Migrants, $19^{\text {th }}$ September 2016, PP. 2: 'We have considered today how the international community should best respond to the growing global phenomenon of large movements of refugees and migrants'.
}

Copyright @ 2020 BORDER CROSSING 
in her view, could thus amount to a tangible manifestation of opinion iuris of States in promoting a global governance of migration and refugee flows (Vitiello, p. 3).

The very fact that States came together to discuss such a broad range of migration issues demonstrates that States have recognised that they need to cooperate to adequately address both drivers and the effects of a global, long-lasting phenomenon. Given that these issues are likely to remain high on the agenda as well as in public opinion's debates, not least with the impacts of climate change exacerbating people's vulnerability, States may agree to adopt soft law instruments on such complicated issues, which are frequently not consistent with national interests. Dealing with migration through non-binding arrangements still leads to monitoring and follow-up process through periodic reviews and maintains a strong focus on these themes (Solomon \& Sheldon, 2018, p. 588).

Criticisms have been advanced not only on the nature of the Global Compact, but also on its content. Contrary to J. Carling's views, the Global Compact for Migration does not refer to 'any kind' of migration (Carling, 2019, p. 2). First of all, it does trace a difference between refugees and migrants to that extent that two separate documents have been drafted, discussed, and adopted. It, however, recognises that frequently the well-founded fear or harm suffered by refugees and migrants are similar, especially during their journey, where no legal status has been yet provided. It is therefore evident that some parts of the Global Compact for Migration and of the Global Compact for Refugees (GCR) address the same issue of vulnerability or crimes committed along the route, such as trafficking in human beings. Second of all, a relevant objective of the GCM is that of addressing the factors that compel people to leave, therefore clarifying the forced nature of the movement.

Nonetheless, as an agreement stemmed from intergovernmental negotiations, the GCM also embeds some weaknesses and gaps. Emblematically, it has been rightly noted that it does not succeed in gathering together the fragmented set of human rights provisions which apply to international migrants (Vitiello, 2018, p. 4), which leads to their different treatment, given the possibility for States to differentiate protection guarantees according to the position of the alien in their territory. However, common implementation of the Global Compact will lead to upholding the human rights of migrants and their assistance, as well as to enriching forms of protection to adequately address their vulnerability and needs.

Furthermore, although the GCM fails in addressing specific aspects concerning the successful integration of migrants - as rightly pointed out by Carling in the case of promoting leadership among female migrants (Carling, 2019, p. 2) - it is nonetheless an instrument of utmost importance that represents a breakthrough in States' approach to migration management, as demonstrated by the Italian position.

Indeed, Italy has been one of the initial promoters of this global attempt since the $2016 \mathrm{UN}$ New York Declaration on Refugees and Migrants ${ }^{13}$, given the overwhelming migratory pressure on its frontiers, especially at sea, and weak compliance by EU member states with the Dublin III Regulation. In June 2017, during the intergovernmental negotiations on migration governance, the former Prime Minister Paolo Gentiloni delivered a speech where he affirmed that Italy '[...]

\footnotetext{
${ }^{13}$ New York Declaration on Refugees and Migrants, United Nations General Assembly A/71/L.1, 13 September 2016, Seventyfirst session
} 
promotes a common responsibility approach in managing the flows to ensure a safe and orderly migration, in protecting people on the move, in enforcing border control, and in tackling issues relating to transnational organised crime, terrorism and illicit trade ${ }^{14}$. In October of the same year, the Institute for Research on Innovation and Services for Development - National Research Council of Italy was one of the academic institutions admitted to attend the preparatory process of the Global Compact, showing that regular pathways to Italy would significantly increase the successful integration of migrants (Institute for Research on Innovation and Services for Development - National Research Council of Italy, 12-12 October 2017).

In September 2018, after the change in government, the new Italian Prime Minister Giuseppe Conte confirmed his predecessor's belief, affirming that 'The migratory phenomenon we are facing requires a structured, multilevel, and short-medium-, and long-term response from the international community as a whole. It is on this basis that we support the Global Compact for Migration and refugees, 15 .

\section{The Semblance}

Alas, at the Intergovernmental Conference in Marrakesh on 10-11 December 2018, Italy abandoned the GCM. UN High Commissioner for Refugees Filippo Grandi considered this withdrawal as 'contradictory for a country directly exposed to unplanned migration flows and which has in the past lobbied for more cooperative approaches at both the European and international levels ${ }^{16}$. The primary aim of this paper is to gather the reasons which led Italy to flee from the Global Compact, and assess whether they were substantiated or led by political propaganda.

The semblance is that there were some ground reasons that made the GCM unacceptable to leading Italian forces. To begin with, the Governments that initially supported the Global Compact were of a different political colour than the one in charge at the moment of its adoption. In December 2018, the two parties in power were the League, represented by the former Deputy Prime Minister and Interior Minister Matteo Salvini, and the 5 Star Movement, whose spokesman and ex-Deputy Prime Minister was Luigi Di Maio. Together formed a centre-right populist executive, whose priorities were to eradicate poverty, stop irregular migration, and reverse the relationship with the EU. Though, the conception of the means of implementation required to reach those aims, the values behind those scopes, and the alliance at the national and EU level to foster their views completely diverged. This permanent and rooted opposition between the two main forces stuck the country several times and, in the case of the Global Compact, firstly resulted in uncertainty and then in Italy's withdrawal, as decided by the Italian Parliament and communicated by the Prime Minister Giuseppe Conte.

Additionally, the Italian Parliament alleges numerous substantial risks in terms of State's sovereignty. The aim of this first section is precisely to report the semblance, i.e. the misleading

\footnotetext{
${ }^{14}$ International cooperation and governance of migration in all its dimensions, including at borders, on transit, entry, return, readmission, integration and reintegration, Panel 2, Speech of Italy, Palais des Nations, Room XIX, Geneva, 19-20 June 2017 https://refugeesmigrants.un.org/sites/default/files/otaly_ts3_p2.pdf

${ }^{15}$ (Gatti, 2018). The video is available in Italian at https://www.youtube.com/watch? $\mathrm{v}=\mathrm{PtfwI} 1 \mathrm{LmPgc} \&$ feature $=$ youtu.be \&t=262

${ }^{16}$ La Voce di New York, 17 December 2018, https://www.lavocedinewyork.com/?p=121200 in (Pastore, 2019)
} 
perception, fuelled by the leading forces of the Government and some associations ${ }^{17}$, that made the GCM appear as an overall peril for Italy's public security and economic wealth.

\section{The Global Compact for Migration: An attempt to annihilate Italian sovereignty?}

F. Ferri correctly argued that the origins of both Compacts trace back to the 2016 New York Declaration on Refugees and Migrants, nonbinding itself, as well as to the 2015 UN Resolution on sustainable development ${ }^{18}$, again, nonbinding (Ferri, 28 October 2019). The 2030 Agenda at the core of the UN Resolution recognised the opportunities of migration and migrants as agents of sustainable development and the need to reach a well-managed migration policy. Explicit and implicit cross-cutting linkages between the 17 Sustainable Development Goals (SDGs) and migration have been meticulously highlighted by UN Agencies. For instance, empowering migrants was an aim set not only in the Global Compact but already in the 2016 New York Declaration and previously in the 2030 Agenda. Similarly, the need to shift migration management from an emergency and temporary model to a more structured governance had been previously addressed. Therefore, it is not immediately clear why some EU Member States, including Italy, have withdrawn from a nonbinding document in line with the contents of formally adopted instruments.

Even more doubts arise if we compare the critics advanced by the political world with the substantial contents of this instrument, whose aim is to promote 'safe, orderly and regular migration', an expression already used in the 2030 Agenda and relaunched in the 2016 New York Declaration. The International Organization for Migration (IOM) ${ }^{19}$ reflected on the existing principles surrounding this notion, and provided useful guidelines to gather the specific features of migration to be promoted through the Global Compact. In the absence of a commonly agreed definition, the UN Migration Agency defines 'orderly migration' ${ }^{20}$ as the regular, legal movement of a person from their usual place of residence to a new one as well as the right of a State to regulate the entry. While the concept of 'orderly migration' focuses on the lawfulness of the movement, it is the (un) authorised channel used to migrate that determines its (ir)regularity.

Whereas these two features share a normative character, the concept of 'safe migration' has more to do with the well-being of migrants and, according to IOM, is not static in nature. In fact, 'the situation of migrants can change from safety, to unsafety throughout the various phases of their migratory process ${ }^{21}$. On this behalf, M. Collyer found that 'to some extent the development of fragmented migration may be seen as a response to increasingly effective immigration controls in the most attractive destinations [...]' (Collyer, 2010, p. 4) that, together with misinformation about the extreme dangers on the journey to Europe, do not allow for a safe access to the EU asylum system.

\footnotetext{
${ }^{17}$ (Centro Studi Macchiavelli, 2018). See below for an in-depth analysis of the declarations made by Italian right-wing parties when discussing the adoption of, or withdrawal from, the Global Compact during Parliamentary sessions

${ }^{18}$ United Nations General Assembly Resolution A/RES/70/1, 25 September 2015, Seventieth session

19 IOM, Facilitation of Safe, Regular and Orderly Migration, Global Compact Thematic Paper, available at https://www.iom.int/sites/default/files/our_work/ODG/GCM/IOM-Thematic-Paper-Facilitation-of-Safe-Orderly-and-RegularMigration.pdf

${ }^{20}$ Idem. Please, see also IOM, Glossary on Migration, 2nd ed., IML No 25, 2011.

${ }^{21}$ Idem, p. 1
} 
All being said, both the target and the aim of the Global Compact seem far from encouraging any kind of irregular cross-border movement, something that can be grasped even by a simple cursory reading of the text. Jean-Claude Juncker argued that a preliminary reading of the Compact would have led to another end ${ }^{22}$.

Additionally, F. Pastore shaped a specific reason of withdrawal, namely a little tangible 'convergence of interests between high and low-income countries in the field of migration' (Pastore, 2019, p. 4) at the basis of some States' hampering attitude. In his view, the grounding aspect that convinced States to undertake the GCR was its keener willingness to establish stronger cooperation between the North and the South to sustain low-income countries in preventing secondary movements, something that is less visible in the GCM. In the case of Italy, the most sceptic voices, which arose in the Chamber of Deputies as well as in the Senate, belonged to the exponents of the League and Fratelli d'Italia (FdI).

For instance, during the discussions upon the Global Compact within the Chamber of Deputies, FdI proposed a motion ${ }^{23}$, whose contents were, in order, the following:

'It [the Global Compact, A/N] originates from the will to promote continuous flows, using both demographic and economic reasons.

[...] the Global Compact creates increasing obligations to States as regards to providing services to migrants, also regardless of their refugee status, and impeding to prosecute who provides illegal assistance to migration. It seems evident, therefore, that the Global Compact is nothing but the umpteenth dowel of a project aimed at annihilating borders, cultures, and, in particular, national sovereignty in the field of migration.

It is unacceptable that migrations are managed by supranational organisms with no democratic control by citizens of single States.

The purely demagogic configuration of the Global Compact, which de facto establishes a sort of < right to migrate $>$ cannot be supported'.

Some of these assumptions were also sustained by the League and Forza Italia ${ }^{24}$, confirming their concerns towards this global instrument. Conversely, left-wing parties highlighted solidarity and coordinated responses to migration as the key merits of this instrument that would have supported the country in building stronger and human rights-based partnerships with EU and extraEU Member States ${ }^{25}$.

\footnotetext{
22 Jean-Claude Juncker argued that 'those countries that decided they are leaving the UN migration compact, had they read it, they would not have done it', in Gotev G., Six EU countries - and counting - back out from the global migration pact, EURACTIV, 12 November 2018, https:/www.euractiv.com/section/justice-home-affairs/news/six-eu-countries-and-counting-back-out-from-the-globalmigration-pact/

${ }^{23}$ Italian Chamber of Deputies, $102^{\text {nd }}$ meeting, Motion No. 1-00080 concerning the signature of the Global Compact for Migration by exponents of Fratelli d'Italia, 18 December 2018, personal translation from Italian

${ }^{24}$ For instance, Forza Italia endorsed assumption no. 1 and 4. See, Italian Chamber of Deputies, Motion No. 1-00099 Motion concerning the signature of the Global Compact for Migration by Forza Italia

${ }^{25}$ Italian Chamber of Deputies, 102nd meeting, Motion No. 1-00089 'Scalfarotto e altri' concerning the signature of the Global Compact for Migration by exponents of centre-left wing party Partito Democratico, 18 December 2018; Italian Chamber of Deputies, 102nd meeting, Motion No. 1-00095 'Fornaro e altri' concerning the signature of the Global Compact for Migration by exponents of the left-wing party Sinistra Italiana, 18 December 2018
} 


\section{Another Perspective: Turning allegations into opportunities}

These allegations, on the one hand, and the lack of a consensual position on this complicated theme among the 5 Star Movement, on the other, led firstly to postpone the decision and then to 'the most spectacular U-turn' (Gatti, p. 3), where the Government decided not to participate in the Marrakesh Conference in late 2018. This second section challenges the aforementioned list of allegations, by directly recalling not only principles of customary law, human rights law, and international refugee law that Italy must comply with, but also the relevant law enforcement promoted by the ECtHR and national Tribunals, therefore showing the groundlessness of most of the arguments used to discredit the Global Compact. It also assesses whether these allegations are consistent with the provisions and aims of the GCM, by means of a meticulous point-by-point analysis. After having verified the legal and practical inconsistency of the major claims not to sign the GCM, the following paragraphs will also unveil both general and specific socio-economic, demographic and political benefits that Italy and the EU would gain through the implementation of adequate migration governance as set out in the Global Compact.

\section{Law and jurisprudence}

International human rights law and jus-cogens principles apply to all migrants, regardless of their status. These encompass the rights to life, liberty, and security; prohibition of torture and inhuman treatment; right to asylum; the principle of non-refoulement, among many others. These human rights are endorsed in treaties as well as in non-binding instruments, included but not limited to, the Universal Declaration of Human Rights (UDHR), the International Covenant on Civil and Political Rights, and the International Covenant on Economic, Social and Cultural Rights, the Geneva Convention relating to the Status of Refugees, the ECHR, the EU Charter and, finally, the Global Compact for Migration.

Calling on States to save lives at sea or condemning all forms of discrimination and racism are not admissions of a 'pro-immigrant manifesto', but a mere recognition of the rights that all migrants are entitled to, on the one hand, and of the obligations States must respect, on the other. Similarly, ensuring their access to basic services as stated in Objective 15 of the GCM responds to human rights provisions, something that States should already provide under binding treaties, notwithstanding the more favourable, non-discriminatory, measures that national authorities might grant to nationals and regular migrants.

The low observance of these basic human rights has frequently brought the Italian Republic in front of the judges in Strasburg. Italy has been, in fact, condemned for violation of Article $3^{26}$ (prohibition of torture), Article 5 (right to liberty and security), Article $6{ }^{27}$ (fair trial), Article $9^{28}$

\footnotetext{
${ }^{26}$ European Court of Human Rights, Case of Khlaifia and others v. Italy, Grand Chamber, Application no. 16483/12, 15 December 2016, Strasbourg, https://hudoc.echr.coe.int/eng\#\{\%22tabview\%22:[\%22document\%22],\%22itemid\%22:[\%22001-170054\%22]\}, where Italy was held responsible also for breaches of Articles 5 and 13

${ }^{27}$ European Court of Human Rights, Case of Markovic and others v. Italy, Application no. 1398/03, Grand Chamber, 14 December 2006, Strasbourg, https://hudoc.echr.coe.int/eng\#\{\%22tabview\%22:[\%22document \%22],\%22itemid\%22:[\%22001-78623\%22]\}

${ }^{28}$ European Court of Human Rights, Case of Saadi v. Italy, Application no. 37201/06, Grand Chamber, 28 February 2008, Strasbourg https://hudoc.echr.coe.int/eng\# \{\%22tabview\%22:[\%22document $\% 22], \% 22$ itemid\%22:[\%22001-85276\%22]\}
} 
(freedom of expression), Article 13 (effective remedy), and Article $14^{29}$ ECHR (nondiscrimination), among others.

Likewise, it is worth mentioning that various national judgments ${ }^{30}$ restored the right to all individuals to civil registration, put in jeopardy by Decree-Law 113/2018, well before the definitive judgment of the Constitutional Court. Italian Tribunals held that denying to asylum seekers the right to registration and the right to residence, the enjoyment of which is conditional upon registration at the registry office, violated the principle of equality enshrined by Article 3 of the Italian Constitution as well as the prohibition of discrimination under Article 14 ECHR. Endorsing the Global Compact would therefore remind and support Italy and the other Member States to observe their responsibilities, avoiding further breaches.

\section{General benefits of the Global Compact for the $\mathbf{E U}$}

The EU is living a long and complex phase of revision of the Common European Asylum System (CEAS). As recently reiterated by the European Commission ${ }^{31}$, a thorough set of norms is needed to fully comply with Article 78 TFEU, which gives competence to the EU to establish a common EU asylum policy for third-country nationals in need of international protection. The first reason why it has failed to provide adequate responses to protect and promote the human rights of people in vulnerability is the negligence of the Member States, which indeed have persistently refrained from correctly applying its provisions. The most emblematic example is the Dublin III Regulation, which clearly considers three hierarchical criteria to be applied in the order in which they are set out, to determine which State is responsible for the evaluation of an asylum request.

The first of the aforementioned criteria concerns the presence of family members who are already beneficiaries of international protection (Article 9) or who have applied for it and are waiting for a first-instance decision (Article 10) in a Member State. Where the applicant falls in the situation pursuant to Article 9 or 10, the Member State responsible for the evaluation of their family members is also responsible for theirs. If this is not the case, the second criterion as set out in Article

\footnotetext{
${ }^{29}$ European Court of Human Rights, Case of Dhahbi v. Italy, Application no. 17120/09, Grand Chamber, 8 July 2014, Strasbourg, https://hudoc.echr.coe.int/eng\#\{\%22tabview\%22:[\%22document\%22],\%22itemid\%22:[\%22001-142504\%22]\}

${ }^{30}$ Civil Court of Florence, Order 361/2019, 18 March 2019, https://bit.ly/2TZ9DTG; Ordinary Tribunal of Bari, Order 16814/2019, 28 February 2019, https://www.asgi.it/wp-content/uploads/2020/03/ordinanza-Tribunale-di-Bari-16814-2019.pdf; Ordinary Tribunal of Bologna, Order 5022/2019, 2 May 2019, https://www.asgi.it/wp-content/uploads/2019/05/Tribunale-di-Bolognaordinanza-del-2-maggio-2019-est.-Betti-xxx-avv.-Zorzella-c.-Comune-di-Bologna-avv.-Montuoro.pdf; Ordinary Tribunal of Genova, Order 2365/2019, 22 May 2019, https://www.asgi.it/wp-content/uploads/2019/05/700-cpc-iscrizione-anagrafica-1.pdf; Ordinary Tribunal of Prato, Order 1183/2019, 28 May 2019, https://www.asgi.it/wp-content/uploads/2019/07/Tribunale-di-Prato-28-maggio2019-est.-Bruno-Xxx-c.-Comune-di-Prato.pdf; Ordinary Tribunal of Lecce, Order 5330/2019, 4 July 2019, https://www.asgi.it/wpcontent/uploads/2019/07/Tribunale-di-Lecce-ordinanza-4-luglio-2019-est.-Barbetta-xxx-avv.-Leuzzi-c.-Comune-di-Lecce.pdf; Ordinary Tribunal of Cagliari, Order 4521/2019, 31 July 2019, https://www.asgi.it/wp-content/uploads/2019/08/Trib.-Cagliariiscrizione-anagrafica.pdf; Ordinary Tribunal of Parma, Order 2379/2019, 2 August 2019, https://www.asgi.it/wpcontent/uploads/2019/08/2019_8_2_Tribunale-Parma-ordinanza-2379-iscrizione-anagrafica-richiedenti-asilo.pdf; Ordinary Tribunal of Catania, Order 12686/2019, $1^{\text {st }}$ November 2019, https://www.asgi.it/wp-content/uploads/2019/11/Tribunale-di-Catania-ordinanza-1novembre-2019-est.-Cosentino-xxx-avv.-Campochiaro-c.-Comune-di-Catania-avv.-Santa-Anna.pdf; Ordinary Tribunal of Rome, Order 62244/2019, 19 November 2019, https:/www.asgi.it/wp-content/uploads/2019/11/Tribunale-di-Roma-ordinanza-25-novembre-2019est.-Di-Tullio-xxx-c.-Comune-di-Pomezia-e-Ministero-dellInterno.pdf; Ordinary Tribunal of Bergamo, Order 8772/2019, 14 January 2020, https://www.asgi.it/wp-content/uploads/2020/02/Tribunale-di-Bergamo-ordinanza-del-14-gennaio-2020-est.-De-Magistris-xxxc.-Comune-di-Boltiere.pdf; Ordinary Tribunal of Palermo, Order 16945/2019, 23 January 2020, https://www.asgi.it/wpcontent/uploads/2020/01/2020_1_23_Tribunale_Palermo_anagrafe_asilo.pdf

${ }^{31} \mathrm{COM}(2020) 609$ final, Communication from the Commission to the European Parliament, the Council, the European Economic and Social Committee and the Committee of the Regions On a New Pact on Migration and Asylum, Brussels, 23.9.2020
}

Copyright @ 2020 BORDER CROSSING 
12 may apply. Accordingly, where the applicant is in possession of a valid residence document or visa, the Member State which issued the document is responsible for examining the application for international protection. This provision also provides hierarchical guidelines to be followed if the applicant owns more than one valid residence document or visa issued by different Member States, or if the required documents have expired. Lastly, only after having assessed that neither the provisions concerning family members nor those relating to valid travel documents pertain to the case, the third criterion concerning the first country of arrival or stay established in Article 13 applies. For its geographical position in the middle of the Mediterranean Sea, Italy and other Southern members have been more exposed than others to sea arrivals, yet the correct application of the hierarchical criteria established in the Dublin III Regulation could have lessened their migratory burden, sharing quotas with other competent EU States.

Objective 4 of the GCM aims at providing all migrants with a proof of legal identity 'upon entry, during the stay and for return as well as to ensure effective migration procedures, efficient service provision, and improved public safety'. Fostering at all levels, civil registry systems and communication technology will help the compliance of the CEAS and bound all Member States to act accordingly.

Another relevant benefit, which the whole EU would gain from comprehensively applying the GCM, concerns the sponsorship of flexible pathways for humanitarian admission as well as for labour mobility and education opportunities, as indicated in Objective 5. Matching skills and facilitating labour mobility in accordance with national and EU market demands on the one hand, and building a common, sound system for humanitarian admission on the other will promote the required shift from a temporary, emergency, highly discretional reception system to a more structured and homogenised mechanism.

Whereas the Commission stated ${ }^{32}$ in 2018 that 'the Union has built a comprehensive long-term strategy on migration covering all aspects of this phenomenon, from saving lives, offering protection to those in need, addressing the root causes of irregular migration', scholars tend to disagree with that. So far, as confirmed by M. Borraccetti, the EU system has focused more on return and removal measures rather than those facilitating common regular migration ${ }^{33}$. Similar investigations have concluded that EU migration policies are 'European-centred' and based mainly on strategies of migration control. In Pascouau's view, 'There has been no consideration of the relevance of, or opportunity to, develop an alternative migratory flow management model on a European level' (Pascouau, 2016, p. 3). Scholars also spotlight the lack of political will in dealing with the phenomenon of migration - whether regular or irregular, high-skilled or low-skilled - as

\footnotetext{
${ }^{32}$ European Commission, Proposal for a Council Decision authorising the Commission to approve, on behalf of the Union, the Global Compact for Safe, Orderly and Regular Migration in the field of development cooperation, COM(2018) 167, 21 March 2018. http://data.consilium.europa.eu/doc/document/ST-7400-2018-INIT/EN/pdf

${ }^{33}$ (Carletti \& Borraccetti, 2018, p. 44). See also Allinson, K., P. Erdunast, E. Guild, T. Basaran, GCM Commentary: The Legal Status of the UN's Global Compact for Safe, Orderly and Regular Migration in International and UK Law, Refugee Law Initiative Blog, 31 January 2019; Carrera, S. and R. Cortinovis, EU's role in implementing Global Compact on Refugees: Contained mobility vs. International Protection, ReSOMA Discussion Brief/ CEPS Paper in Liberty and Security in Europe, April 2019, CEPS, https://www.ceps.eu/ceps-publications/eus-roleimplementing-un-global-compact-refugees/; Crépeau, F., Towards a Mobile and Diverse World: 'Facilitating Mobility' as a Central Objective of the Global Compact for Migration, 2018, International Journal of Refugee Law, $30(4), 650-656$
} 
demonstrated by recent tragic events ${ }^{34}$. This is particularly true in the realm of labour migration, where the EU still needs to coordinate and harmonise national standards on the admission of migrant workers (Pascouau, 2015, p. 3). However, the recently released European Commission's New Pact on Migration and Asylum seems to replicate the approach already endorsed by its predecessors ${ }^{35}$. If the intention is that of achieving the 'comprehensive long-term strategy on migration' overstated by the Commission, the EU should take the GCM as a general guideline on which more efficient and exhaustive arrangements need to be based (Carrera, Lannoo, Stefan, \& Vosyliūté, 2018, p. 3).

Looking at the EU external dimension, several Objectives help revitalise the image of the EU as defender of human rights and democratic freedoms. For instance, sustaining middle- and lowincome countries in addressing adverse drivers of forced migration through financial investments, entrepreneurship, education training, employment programmes and partnerships will give people the choice to stay in their own country while respecting human rights and fundamental freedoms. The GCM promotes this approach devoted to common solidarity and comprehensive partnership in opposition to the easier, yet human rights-breaching, praxis of externalisation of borders.

\section{General benefits of the Global Compact for Italy}

All the advantages outlined for the EU accordingly apply to Italy. Overall, the collective effort to achieve Objective 4 on legal identity would allow the first two hierarchical criteria of the Dublin III Regulation to take place, with a double immediate effect: 1) when these criteria apply to the case, designated EU countries other than the first entered should thus take on their responsibilities for the evaluation of the international protection request; 2) a subsequent, initial redistribution of migrants first arriving in Italy would finally start.

Similarly, if Objective 5 on pathways for regular migration is seriously implemented, EU institutions and Member States should then adopt and promote the use of humanitarian visas to regularly and safely travel to Europe for international protection purposes. Here again, the Italian burden would be relieved and thousands of lives would be spared. Besides, the GCM represents the first-ever concerted international network for migration management. This would give Italy the unique opportunity to raise its voice to focus the international attention on national issues on migration, and calling for even greater solidarity and cooperation, making both the EU and its Member States responsible in front of the whole international community for their lack of commitment. Beyond these general positive outputs that pour out of the national level, the aim of this last section is to turn the former allegations used to discredit the Global Compact into actual benefits for Italy.

\section{Specific benefits for Italy}

The following section gives a specific overview of the main benefits that the Global Compact would bring to Italy, transforming the allegations advanced by FdI into factual opportunities to enhance the country's socio-economic growth and cultural development, while promoting a human rights-based migration governance.

\footnotetext{
${ }^{34}$ European Commission Press release: A European taskforce to resolve emergency situation on Lesvo, 23 September 2020 , Brussels, available at https://ec.europa.eu/commission/presscorner/detail/en/ip_20_1728

${ }^{35} \mathrm{COM}(2020) 609$ final
}

Copyright @ 2020 BORDER CROSSING 
166 Fleeing from the Global Compact for Migration: A missed opportunity for Italy

\section{Demographic and economic resources}

Presumably, the demographic and economic reasons behind the promotion of continuous migration flows FdI referred to, concerned the inexorable decline in EU's fertility and mortality rate that is leading the EU to be the world's most rapidly ageing region after Japan ${ }^{36}$.

Indeed, EUROSTAT future projections regarding the population expansion in the EU Member States confirm a demographic slowdown, such that within four decades the total number of inhabitants in the EU is projected to stagnate (EUROSTAT, 2015). The UN Development Programme confirmed this estimation, arguing that, in a zero-migration scenario, as late as 2025 , only New Zealand and Ireland would still have growth in their working-age population (Apap, 2019, p. 2). The demographic decline we are living in has self-evident repercussions in the labour market. The share of the working-age population in the former EU-28's total population is, in fact, expected to decrease, with an overall reduction during the examined period of 44.5 million persons. Conversely, the share of the elderly is projected to increase from 97.7 million to 151.0 million by 2080 (EUROSTAT, 2015, p. 138). In other words, by 2080, there will be less than two persons of working-age for each elderly person.

The Italian demographic landscape does not draw a happier scenario. The case of the Basilicata region $^{37}$ in Southern Italy illustrates the slowdown in terms of population growth and the converse trend in population ageing that characterises the whole peninsula: it is estimated that by 2050 , there will be 53 twenty-year-olds out of 100 over-seventy-year-old Lucanians. The Italian demographic gap cannot be fully explained solely by mentioning the decrease in the fertility rate and the increase in life span, but also taking into account the national emigration rate that, according to $\mathrm{IOM}^{38}$, in the period 2007-2016 has increased and is currently higher than the number of citizens who return from abroad. According to the 2018 report on foreigners in the Italian labour market realised by the Italian Ministry of Labour, 'over the last few years, the foreign component in the labour market has become key in the Italian economy, not only because of the importance that foreign workers have had and continue to have in the performance of specific tasks, but also by virtue of the compensatory effect they have determined [...]' (Ministero del Lavoro e delle Politiche Sociali, 2018, p. 3).

In this critical scenario, migration could contribute to filling both the demographic and labour gap that EU citizens alone cannot manage. For instance, migration can raise tax revenues and social contributions, which can then be spent on ageing populations (OECD, 2014). However, the Global Compact's acknowledgment of this state of affairs does not entail opening the gate to uncontrolled inflows of irregular migrants into the territory of EU Member States or Italy.

Concerning the role that migration is playing in the Italian labour market, it is relevant to note that the total working-age foreign population is about of 4milion people, half of which are employed. As portrayed by IOM, migrant and native workforce tends to both concentrate in complementary labour sectors, thus avoiding competition with nationals. Most foreign workers are employed in very specific sectors, such as the service sector (57\% of the total), agriculture $(16,6 \%)$, cleaning, and care. Frequently, hence, both male and female migrant workers are overrepresented

\footnotetext{
${ }^{36}$ (EUROSTAT, 2015, p. 22). It should be noted that these projections embrace all former 28 EU Member States, Great Britain included

${ }^{37}$ (Coniglio \& Prota, 2003). See also, Coniglio N.D., 2019, Aiutateci a casa nostra. Perché l'Italia ha bisogno degli immigrati

${ }^{38}$ IOM, Migrants' contributions to Italy’s welfare, IOM Italy Briefing, Issue No. 2, October 2017
} 
in low-skilled occupations ( $37 \%$ versus $8 \%$ Italians) $)^{39}$. Conversely, less than $10 \%$ of migrants are employed in high-skilled occupations. An emblematic example of economic opportunities of migrant entrepreneurship is the emerging Chinese migrant enterprises in the Italian textile sector, which in Prato and Carpi have led to the revitalisation of the market ${ }^{40}$.

On the other hand, IOM found that irregular migrants in Italy tend to concentrate in sectors in which labour law enforcement is weak and control is almost absent. It is not a coincidence that the highest percentage of irregular employees concerns agriculture, where $41 \%$ is estimated to be irregularly employed, followed by $27 \%$ in retail and trade ${ }^{41}$.

The more migrants are active in the labour market, the better for national economic demand and supply. For instance, F. Furlanetto and O. Robstad found that a positive immigration shock lowers unemployment rates even among native workers, and has a measurable positive effect on public finances in the short-run (Furlanetto \& Robstad, 2016). These results fit with the predominant thesis in literature, according to which there are significant long-term benefits in terms of a higher GDP per capita for countries of destination (Jaumotte, Koloskova, \& Saxena, 2016).

This positive correlation has remained unchanged despite the wide quantitative and qualitative transformation of migration inflows over the decades. For instance, back in 2004, immigrants were estimated to spend around 30 euros/month on phone cards, and they also had a positive impact on the use of public transportation (Ricci, 2004). Italian wealth is shaped by migrants as well, producing $8.9 \%$ of the total GDP (around 130 billion euros) only in 2016 (Fondazione Moressa, 2017). In addition, migrants actively contribute to the production of Italian welfare, as demonstrated by numerous institutional sources. In 2016 , foreign workers deposited $€ 8$ billion to the Italian social security system and received around 5 billion euros in social security benefits, according to the National Institute for Social Security ${ }^{42}$. Migrants' net contribution to the Italian social security system is therefore of 3 billion euros. Between 1960 and 2016, foreign workers have contributed $€ 241.2$ billion to the Italian social security system in social security benefits accrued, net of the pension benefits they will receive over their entire life cycle ${ }^{43}$. Moreover, up to now, there has been little evidence to the concern that immigrants depress wages of native workers (Peri, 2014), rather the prevailing opinion in the literature on average salaries is that, given the wage growth stagnation and worsening of working conditions in Western countries over last thirty years, the immigrant workforce in the Italian job market slightly increases the native wages.

\section{Integrated border management}

Another widely shared presumption among Italian parties and voters is that this non-legally binding document of global migration governance, agreed by national sovereign entities, would

\footnotetext{
${ }^{39}$ Idem, p.3

${ }^{40}$ (Barberis, Bigarelli, \& Dei Ottati, 2011). For a deep analysis of immigrant entrepreneurship in the Italian city of Prato, see Dei Ottati G. (2013), "Imprese di immigrati e distretto industriale: un'interpretazione dello sviluppo delle imprese cinesi di Prato", Stato e Mercato, n. 98, agosto. Pp. 171-203. For a general overview of the role of migrants in shaping the Italian sector of small industries, see Chiesi A.M. (2011), "Il ruolo degli imprenditori immigrati nello sviluppo della piccola impresa in Italia", in CNEL, Il profilo nazionale degli immigrati imprenditori, Cnel, Roma, pp. 6-22.

${ }^{41}$ Idem, p. 5

42 INPS, XVI Rapporto Annuale, Istituto Nazionale Previdenza Sociale, July 2017, available in Italian at https://www.inps.it/docallegatiNP/Mig/Dati_analisi_bilanci/Rapporti_annuali/INPS_XVI_Rapporto_annuale_intero_030717\%20.pdf

${ }^{43}$ Idem, p. 135
} 
boycott national sovereignty in the field of migration, also leading to other catastrophic scenarios, such as the eradication of borders and native cultures.

Conversely, one of the guiding principles of the Global Compact explicitly concerns the acknowledgment of the sovereign right of States to determine their national migration policy and their prerogative to govern migration within their jurisdiction. Its statements also recognise that within their sovereign jurisdiction, States may distinguish between regular and irregular migration statuses.

Equally, Objective 11 directly deals with border management, thus emphasising their enhanced security rather than anticipating their dissolution. Furthermore, the allegation's attempt to demolish national sovereignty by impeding national authorities to prosecute illegal assistance to migrants does not find any reference in the GCM in general, and in Objective 8 in particular, which rather calls for a shared commitment to save lives and prevent migrant losses by means of individual or joint SAR operations, ensuring that the provision of pure humanitarian assistance, primarily provided by NGOs, is not considered unlawful.

As far as it concerns the assumption that the Global Compact would annihilate cultures, besides sovereignty and borders, FdI's motion clarifies this aspect in the following terms:

'Italy is one of the Southern borders of the European Union and, broadly speaking, of the Western world; hence, Italy can be considered as the <entrance door $>$ to Western civilisation, to its lifestyle, rights and duties. Affirming the principle that everyone could freely have access to our nation, and therefore to Europe, would entail a truly genetic mutation of the functional dimension of the border [...], meant not only as a line of territorial demarcation [...], but also as a line of demarcation between two different civilisations, with respectively different characteristics, and the necessary differences, ${ }^{44}$.

This passage seems to recall two well-known historical and political distinctions. The first one relies upon the dichotomy between the autonomous movements of people in search of safety or of a better life perceived as illegitimate in contrast with the only acceptable form of mobilities, namely those organised and authorised by States ${ }^{45}$. The second pertains to the difference between the wealthy, powerful, developed Europe (or the North) and the poor, powerless, developing Africa ${ }^{46}$ (or the South). In the aforementioned declaration, borders are depicted as both symbolic and concrete demarcation between the 'familiar of here and the unfamiliar of there' (Musarò, 2013, $\mathrm{p}$. 42 ), or in other words, between $u s$ and them, performing the role of ordering society (Popescu, 2011). In light of this division, it has been affirmed that borders are socially constructed to serve the political purpose of creating and reinforcing national identity as well as national sovereignty and territory. In reflecting on the linkages between national sovereignty and national identity, C. Cantat straightforwardly affirmed that 'It is precisely the capacity to make these distinctions, to separate what qualifies as 'normal' and acceptable political identities, spaces and practices from what constitutes the exception, the abnormal, which provides the foundation of sovereignty' (Cantat,

\footnotetext{
${ }^{44}$ Italian Chamber of Deputies, $102^{\text {nd }}$ meeting, Motion No. 1-00080 concerning the signature of the Global Compact for Migration by exponents of Fratelli d'Italia, 18 December 2018, personal translation. Senate exponents of Fratelli d'Italia presented the same text during the $65^{\text {th }}$ meeting, 29 November 2018

45 (Rajaram, 2015). See also (Cantat, 2016)

${ }^{46}$ Musarò P., 'Africans'vs. 'Europeans': Humanitarian narratives and the moral geography of the world, in (Musarò \& Parmigiani, Beyond Humanitarian Narratives, 2013, p. 38)
} 
2016, p. 14). Similarly, P. Musarò interpreted borders as fabrications that political institutions make to legitimate distinctions between civilisations that they could not otherwise sustain (Musarò, $\mathrm{p}$. 57).

The concept of national identity is dynamic, as it is affected by changes in space and time. The dimension of $u s$ in terms of Italian belonging could be still put into question, owing to a persistent economic, social, infrastructural, welfare gap between the Centre-North and South of the country, since 1861. Vast differences also endure in the public health and care systems, as the Covid-19 pandemic openly showed. Besides, for at least two decades, the League party, with also a young Matteo Salvini, based its political consensus on the call for separatism from the South. Covering State's inherent political and identity issues with external variables is at the core of De Genova's study of the 'border spectacle' (De Genova, 2015). Accordingly, spectacular mediatic scenes of enforcement at the border, where irregular migrants are stopped and returned, serve the purpose of naturalising the exclusion of 'the others' justified by the need to protect national integrity.

In Crépeau's analysis on human mobility, he found that in spite of the propagandistic discourses of political leaders, States already know that the facilitation of regular migration is a much better solution than its prohibition (Crépeau, 2018, p. 651), and that the GCM facilitates the making of regular migration pathways in various ways. Most importantly for States, the GCM encourages the development of an effective border management that could support States in achieving national security in compliance with international law, while also protecting the rights of migrants and reducing their vulnerability. In 2015, IOM launched a multidimensional Migration Governance Framework ${ }^{47}$ to help States in developing a well-managed migration policy, responding to Target 10.7 of the 2030 Agenda on Sustainable Development. To meet this goal, restated also in the GCM, migration management in terms of border control was deeply analysed and four main areas of interventions were found ${ }^{48}$ :

Identity management. To enhance the flows of information of those crossing borders, Objective 4 of the Global Compact suggests enforcing the global efforts to register all citizens at birth, and to facilitate the issuance of reliable identity documents. To ensure the systematic identification of false or fraudulent travel documents, States may also rely on international organisations' expertise on travel document inspection. Moreover, Objective 11 envisages the use of communication technology, pre-screening and border crossing procedures, bearing in mind the full respect of the principle of non-discrimination as well as the right to privacy.

Border Management Information Systems. States parties of the Schengen Agreement can rely on the large flows of information and technical support provided by the Visa Information System on visa application, the Schengen Information System II on immigration purposes, and EURODAC on asylum. The significant contribution provided by this kind of regional border management cooperation at disposal of Member States, especially those at the external frontiers of the EU, is acknowledged by Objective 11 of the GCM.

\footnotetext{
${ }^{47}$ IOM Council, Migration Governance Framework: The essential elements for facilitating orderly, safe, regular and responsible migration and mobility of people through planned and well-managed migration policies, C/106/40, 4 November 2015

${ }_{48}$ IOM, Border Management, Global Compact Thematic Paper, https://www.iom.int/sites/default/files/our_work/ODG/ GCM/IOM-Thematic-Paper-Border-Management.pdf
} 
Integrated Border Management (IBM). The European Commission ${ }^{49}$ launched the concept of IBM to achieve the goal of having open, but controlled and secure borders, by enhancing the coordination and cooperation among all relevant border authorities at national and international levels. To meet this aim, IBM strengthens closer cooperation between Governments and their own immigration services and those of other countries to maximise the efficient and effective use of resources at borders.

Humanitarian Border Management (HBM). IOM's Migration Crisis Operational Framework emphases the role of HBM as a way to protect vulnerable groups in case of cross-border movement and to ensure the respect of their right to non-refoulement. Objective 11 embodies the need to provide timely assistance and protection of migrants in situation of vulnerability, while guaranteeing the respect of the best interest of the child in case of detected migrant minors. HBM includes, inter alia, assistance and preparedness to sudden mass inflows and emergencies, and creating inter-agency cooperation mechanisms for a coherent response during crisis.

Italy, and the EU Member States alike, could benefit from these international guidelines to both enhance national security and respect their international commitments.

\section{Democratic control over migration}

The Global Compact for Migration ${ }^{50}$, akin to the GCR, espouses a whole-of-society approach, meaning the active and meaningful participation of refugees, migrants, host community members and organisations in the implementation of GCM's guidelines as well as in its follow-up and review at all policy levels, from the international to the local one. For this reason, a whole-of-society approach also envisages a whole-of-government approach, which includes both horizontal and vertical policy coordination (Domicelj \& Gottardo, March 2019). These stem from the 2030 Agenda and the 2016 New York Declaration, where the need for a more integrated, cross-cutting, participatory approach to migration was first expressed to respond to the multidimensional, multilevel, and cross-sectorial reality of the phenomenon.

For the wide, broad, multilevel, and multi-stakeholder engagement in all phases of the GCM, it can be argued that the Global Compact rather enhances the democratic control over migration. Correlated benefits include an international prominence of national migration-related issues as well as multilevel, multi-stakeholder participatory engagement. In fact, the inclusion of civil society organisations in the implementation of the GCM is essential, not only for the process to be inclusive and holistic, but also for the crucial roles these actors play as agents of accountability, advocacy, service and data delivery.

For this reason, presuming that the United Nations, by means of a non-binding document, are attempting to limit the democratic debate on migration seems inconsistent. Conversely, Italy will benefit from committing to the GCM also in terms of democratic participation and control over migration.

49 European Commission, Guidelines for Integrated Border Management in European Commission External Cooperation, November 2010

${ }^{50}$ Preambular Paragraph No. 15, Global Compact for Migration 


\section{The establishment of regular pathways}

Article 13.2 UDHR establishes a right to leave a country ${ }^{51}$ in the following terms: 'Everyone has the right to leave any country, including his own, and to return to his country'. Article 12.2 of the 1966 International Covenant on Civil and Political Rights and Article 2.2 of the Protocol $n^{\circ} 4$ ECHR equally recognise this right. The right to leave a country, be it one's country of citizenship or current residence, is essential to the fulfilment of other rights and principles, most notably the right to asylum that begins with the flight from their country of origin or residence and continues with the hosting State's duty to individually evaluate the correspondent international protection claim.

However, it does not entail a so-called 'right to migrate' (Carrera, Lannoo, Stefan, \& Vosyliūtè, p. 6), meant by FdI and other right-wing parties as an unconditional, uncontrolled, unauthorised free entry of whoever accidentally crosses the Italian territory. Louise Arbour, UN Special Representative for International Migration, straightforwardly sustained that 'It is not correct to suggest that this Compact imposes obligations on Member States and infringes on their sovereignty. It does nothing of the sort, and it is not binding, as a treaty would be. It does not create a right to migrate. Under international human rights law citizens of a country have the right to enter, stay and leave their country but they don't have a right to go anywhere else unless they seek asylum, or are authorised by another country to enter its territory. ${ }^{52}$

Accordingly, the Global Compact seeks to prevent irregular migration ${ }^{53}$, and rather aims at opening flexible pathways for regular migration to facilitate labour mobility in accordance with national labour market's needs, and to improve education opportunities through bi/multilateral labour agreements, cooperation arrangements, and academic exchanges just to name a few. These serve a double purpose: helping to fill the evident demographic, labour, and educational gap in most EU countries, Italy included, while meeting the needs of migrants, addressing their major vulnerabilities.

Facilitating mutual recognition of skills, qualification, and competences (Objective 18), promoting labour mobility cooperation and education opportunities (Objective 5) on the one hand, and establishing common rules and programmes for humanitarian admission, on the other, will promote regular migration in the first place, while enhancing national control over migration inflows in the second place. Migrants will be able to significantly contribute to Italian socio-cultural and economic development and welfare for the benefit of the entire community. Consequently, Italy will come a step closer to the achievement of sustainable development enclosed in the 2030 Agenda (Crépeau, p. 4). Similarly, ensuring humanitarian admission for people at risk and providing migrants with internationally required standards of basic services will foster Italian sustainable development, while sparing thousands of lives.

\footnotetext{
${ }^{51}$ For an in-depth overview of ius migrandi and ius emigrandi, see (Mazzarese, 2020)

${ }^{52}$ Louise Arbour, Statement at Press Briefing Marrakesh, 11 December 2018, p. 2, http://www.un.org/en/conf/migration/assets/ pdf/Press-Briefing-11.12.2018-SRSG-Arbour.pdf.

${ }^{53}$ Objective 7, paragraph 23(h), Objective 9, paragraph 25(c, Objective 11, paragraph 27 of the Global Compact for Migration
} Copyright @ 2020 BORDER CROSSING 


\section{Conclusion}

Gatti argues that 'European populists do not seem to have a problem with the Global Compact for Migration, they have a problem with migration as such [...]. The exit from the Global Compact is not a policy choice related to the content of this document. It is nothing more than populist propaganda, that can hardly be negotiated away' (Gatti, 2018, p. 1).

Exactly for this reason, this paper demonstrated the multiple political and legal shortcomings of such propagandistic attitude in the case of Italy. The first section illustrated the economic, demographic, and political reasons that led Italy to abandon the Global Compact, which has been shared by the leading forces during Parliamentary discussions in late 2018. By depicting the GCM as a threat to the overall Italian sovereignty in the realm of migration, the country in fact refrained from an international instrument, which it initially supported to alleviate the migratory burden through a stronger partnership with third countries of origin and enhanced dialogue with the other EU Member States. The second section showed the merits and the weaknesses of this soft law instrument, underlining the GCM's potential contribution to customary law. Moreover, the second part assessed the inconsistency of the advanced allegations, which have been first contested with objective facts and data provided by reliable literature and institutional sources, as well as by national and supranational jurisprudence. These misleading claims were then turned into general benefits for a more comprehensive and human rights-based migration governance at the EU and domestic level. The last section shed light on the specific benefits that Italy would gain through the adoption of the Global Compact in terms of demographic and economic resources, enhanced border management, stronger democratic control over migration, and the creation of regular migration pathways, including for labour mobility and educational opportunities.

\section{References}

Allinson, K., Erdunast, P., Guild, E., \& T., B. (2019, January 31). also Allinson, K., P. Erdunast, E. Guild, T. Basaran, GCM The Legal Status of the UN's Global Compact for Safe, Orderly and Regular Migration in International and UK Law. Refugee Law Initiative Blog.

Amnesty International. (12 December 2017). Libya: European governments complicit in horrific abuse of refugees and migrants. Amnesty International. (2018). Report: Libya 2017/2018.

Amnesty International. (2020, January 30). Libya: Renewal of migration deal confirms Italy's complicity in torture of migrants and refugees. Retrieved from https://www.amnesty.org/en/latest/news/2020/01/libya-renewal-of-migration-deal-confirmsitalys-complicity-in-torture-o

ANSA. ANSA, Migranti: Di Maio, ONG hanno trasportato criminali, 23 April 2017, https://www.ansa.it/sito/notizie/ politica/2017/04/23/migranti-di-maio-ong-hanno-trasportato-criminali-_48c4044a-7c54-42a0-ae81-99464536f076.html 2017, April 23). ANSA Notizie. Retrieved from https://www.ansa.it/sito/notizie/politica/ 2017/04/23/ migranti-di-maio-onghanno-trasportato-criminali-_48c4044a-7c54-42a0-ae81-99464536f076.html

Apap, J. (2019, January). Apap J., A global compact on migration: Placing human rights at the heart of migration management, European Parliamentary ReEuropean Parliament Briefing. Retrieved from https://www.europarl. europa. eu/RegData/etudes/BRIE/2017/614638/EPRS_BRI(

Arbour, L. (2018, December 11). Statement at Press Briefing Marrakesh.

Barberis, E., Bigarelli, D., \& Dei Ottati, G. (2011). Distretti industriali e imprese di immigrati cinesi : rischi e opportunità con particolare riferimento a Carpi e Prato. In M. Bellandi, \& A. Caloffi, Innovazione e trasformazione industriale, la prospettiva dei sistemi di produzione locale italiani (pp. 43-62). Bologna: Il Mulino.

Betts, A. (2010). Global Migration Governance - the Emergence of a New Debate. Oxford University Press.

Bjerre, L., Helbling, M., Römer, F., \& Zobel, M. (2014). Conceptualising and Measuring Immigration Policies: A Comparative Perspective. International Migration Review.

Boyle, A., \& Chinkin, C. (2007). The making of international law. Oxford University Press.

Cantat, C. $(2016,2)$. Rethinking Mobilities: Solidarity and Migrant Struggles Beyond Narratives of Crisis. Intersections. East European Journal of Society and Politics, pp. 11-32.

Carletti, C., \& Borraccetti, M. (2018). Il Global Compact sulla migrazione tra scenari internazionali e realtà europea. Freedom, Security \& Justice: European Legal Studies(2). 
Carling, J. (2019). Three reasons for rejecting a 'Global Compact for Most Migration'.

Carrera, S., \& Cortinovis, R. (2019, April). EU's role in implementing Global Compact on Refugees: Contained mobility vs. International Protection. ReSOMA Discussion Brief/ CEPS Paper in Liberty and Security in Europe.

Carrera, S., Lannoo, K., Stefan, M., \& Vosyliūte, L. (2018). Some EU governments leaving the UN Global Compact on Migration: A contradiction in terms? CEPS Policy Insights(2018-15).

Centro Studi Macchiavelli. (2018). Dossier No. 9: I global compact su migrazioni e rifugiati.

Chimni, B. S. (2018). Global Compact on Refugees: One Step Forward, Two Steps Back. International Journal of Refugee Law, $630-634$.

Collyer, M. (2010). Stranded Migrants and the Fragmented Journey. Journal of Refugee Studies.

Coniglio, N., \& Prota, F. (2003). Human Capital Accumulation and Migration in a Peripheral EU Region: the Case of Basilicata.

Crépeau, F. (2018). Towards a Mobile and Diverse World: 'Facilitating Mobility' as a Central Objective of the Global Compact on Migration. International Journal of Refugee Law, 30(4), 650-656.

Crépeau, F. (2018). Towards a Mobile and Diverse World: 'Facilitating Mobility' as a Central Objective of the Global Compact on Migration, 2018. International Journal of Refugee Law, 30(4), 650-656.

Cusumano, E., \& Villa, M. (22 November 2019). Sea Rescue NGOs: a Pull Factor of Irregular Migration? Migration Policy Centre, Robert Schuman Centre for Advanced Studies, European University Institute.

De Genova, N. (2015). The 'order spectacle of migrant “"victimisation”. Open Democracy.

De Genova, N. (2018). Migration and the Mobility of Labor. In M. Vidal, T. Smith, T. Rotta, \& P. Prew, The Oxford Handbook of Karl Marx.

Del Guercio, A. (2018). Dal decreto Minniti-Orlando al decreto Salvini: decretazione d'urgenza, securitizzazione della politica d'asilo e compressione dei diritti fondamentali. Quando la legge genera vulnerabilità. In d. \&. Visconti (Ed.), Persone fragili: La vita psichica dei migranti forzati tra cura ed esclusione.

Domicelj, T., \& Gottardo, C. (March 2019). Implementing the Global Compacts: the importance of a whole-of-society approach. Forced Migration Review online.

European Commission. (1 February 2019). European Commission, Opinion of the LegaThe legal effects of the adoption of Global Compact for Safe, Orderly and Regular Migration. Brussels.

European Commission. (4 April 2016). Press Release, Fact Sheet, Implementing the EU-Turkey Agreement - Questions and Answers. Brussels.

European Parliamentary Research Service. (2019). A global compact on migration: Placing human rights at the heart of migration management. European Parliament Briefing.

EUROSTAT Eurostat, Statistic Explained: Asylum Statistics. Retrieved from http://ec.europa.eu/eurostat/statisticsexplained/index.php?title $=$ Asylum_statistics

EUROSTAT. (2015). People in the EU: who are we and how do we live?

Ferri, F. (28 October 2019). I patti globali su migrazioni e rifugiati tra vecchie e nuove dinamiche multilivello: alcune considerazioni di natura giuridica. Questione Giustizia.

Fondazione Moressa. (2017). Rapporto annuale sull'economia dell'immigrazione - La dimensione internazionale delle migrazioni.

Frelick, B. K. (2016). The Impact of Externalisation of Migration Controls on the Rights of Asylum Seekers and Other Migrants. Journal on Migration and Human Security, 4(4), 190-220.

Furlanetto, F., \& Robstad, O. (2016). Immigration and the Macroeconomy: Some New Empirical Evidence.

Gatti, M. (2018, December 14). EU Migration Law Blog.

Global Detention Centre. (30 August 2018). Immigration Detention in Libya: "A Human Rights Crisis".

Gotev, G. (2018, November 12). Euractiv. Retrieved from Gotev G., Six EU countries - and counting - back out from the global migration pact, Ehttps://www.euractiv.com/section/justice-home-affairs/news/six-eu-countries-and-counting-back-outfrom-the-global-migration-pact/

Hannikainen, L. (2006). Customary Law: Are Rumours of Its Death Exaggerated? . Baltic Yearbook of International Law, 125141.

Helfer, L., \& Wuerth, I. (2016). Customary International Law: An Instrument Choice Perspective. Michigan Journal of International Law, 563-608.

Helfer, L., \& Wuerth, I. (n.d.). Working paper: Custom in the Age of Soft Law .

Heller, C., \& Pezzani, L. (2018). Blaming the Rescuers. Criminalising Solidarity, reinforcing Deterrence. Forensic Architecture Agency - Goldsmith University.

Human Rights Watch. (25 July 2018). EU/Italy/Libya: Disputes Over Rescues Put Lives at Risk.

Institute for Research on Innovation and Services for Development - National Research Council of Italy. (12-12 October 2017). Regular and Undocumented Migrants, Fundamental Rights, Decent Work, and Integration in Italy: The Case of the Campania Region. Geneva.

IOM. (2011). Glossary on Migration (2nd Edition ed.).

IOM. (4 November 2017). IOM Learns of 'Slave Market' Conditions Endangering Migrants in North Africa. 


\section{Fleeing from the Global Compact for Migration: A missed opportunity for Italy}

IOM. Facilitation of Safe, Regular and Orderly Migration, Global Compact Thematic Paper.

Italian Chamber of Deputies, 102nd Session. (18 December 2018). Debate on the adoption of the Global Compact for Migration. Rome.

Jaumotte, F., Koloskova, K., \& Saxena, S. (2016). Impact of Migration on Income Levels in Advanced Economies.

Mazzarese, T. (2020). Diritto di migrare e diritti dei migranti. Una sfida al costituzionalismo (inter)nazionale ancora da superare. Diritto, Immigrazione, Cittadinanza.

Ministero del Lavoro e delle Politiche Sociali. (2018). VIIIRapporto annuale. Gli stranieri nel mercato del lavoro.

Musarò, P. (2013). 'Africans' vs. 'Europeans': Humanitarian narratives and the moral geography of the world. (M. \&. Parmigiani, Ed.) Sociologia della Comunicazione, Beyond Humanitarian Narratives(45).

Musarò, P., \& Parmigiani, E. (2013, 45). Beyond Humanitarian Narratives. Sociologia della Comunicazione.

New York Declaration for Refugees and Migrants (19 September 2016).

Newland, K. (2018). The Migration Compact: An Unlikely Achievement. International Journal of Refugee Law, 30(4), 657660.

Nyers, P. (2019). Humanitarian hubris in the global compacts on refugees and migration. Global Affairs, 171-178.

OECD. (2014). Migration Policy Debates.

OHCHR. (2019, July 18). OHCHR Press Release. Retrieved from https://www.ohchr.org/en/NewsEvents/ Pages/DisplayNews.aspx?NewsID $=24833 \&$ LangID $=\mathrm{E}$

OHCHR. (25 February 2016). UN report documents litany of violations and abuses amid chaos in Libya.

Pascouau, Y. (2015). EU Labour migration policy by other means? Fieri working papers.

Pascouau, Y. (2016). A Jobseeker's visa: Towards a new mobility policy for third-country nationals. Jacques Delors Institute.

Pastore, F. (2019). Not So Global, Not So Compact. Reflections on the Shitstorm Surrounding the Global Compact for Migration. Istituto Affari Internazionali.

Peri, G. (2014). Do immigrant workers depress the wages of native workers? IZA World of Labor.

Popescu, G. (2011). Bordering and Ordering the Twenty-first Century: Understanding Borders. Rowman \& Littlefield Publishers.

Rajaram, P. (2015). Beyond crisis: Rethinking the population movements at Europe's border. FocaalBlog.

Refugees Deeply. (October 2017). European Priorities, Libyan Realities.

Ricci, A. (2004). The impact of immigration on Italy's society: Technical Report.

Rita, A. (2019). Guiding Principles of the Global Compact on Migration. The Relevance of migration for the 2030 Agenda for Sustainable Development.

Roberts, A. (2001). Traditional and Modern Approaches to Customary International Law: A reconciliation. American Journal of International Law, pp. 757-791.

Solidar. (2019, August 6). Solidar. Retrieved from https://www.solidar.org/en/news/italy-is-now-formally-criminalizingsolidarity

Solomon, M. K., \& Sheldon, S. (2018). The Global Compact for Migration: From the Sustainable Development Goals to a Comprehensive Agreement on Safe, Orderly and Regular Migration. International Journal of Refugee Law, 30(4), 584-590.

Speech of Italy. (19-20 June 2017). International cooperation and governance of migration in all its dimensions, including at borders, on transit, entry, return, readmission, integration and reintegration. Geneva.

Stefanoni, F. (2018, August 14). Corriere della Sera. Retrieved from https://www.corriere.it/politica/18_agosto_14/di-maio-1accusa-patto-ong-scafisti-magistrati-archiviano-605bfd50-9fa3-11e8-9437-bcf7bb

UN Press Release. (28 November 2017). High Commissioner for Refugees Calls Slavery, Other Abuses in Libya 'Abomination' That Can No Longer Be Ignored.

UNHCR. (17 October 2017). Libya: Refugees and migrants held captive by smugglers in deplorable conditions.

Villa, M., Corradi, E., \& Villafranca, A. (2018). Fact Checking: migrazioni 2018. ISPI.

Villegas Ergueta, M. (2015, December). The multifaceted and dynamic interplay between hard law and soft law in the field of human rights. Ciencia y Cultura, pp. 185-202.

Vitiello, D. (2018, 3). Il contributo dell'Unione Europea alla governance internazionale dei flussi di massa di rifugiati e migranti: Spunti per una rilettura critica dei Global Compacts. Diritto, Immigrazione e Cittadinanza.

Vosyliūte, L. (December 2019). What is the EU's role in implementation of the Global Compact for Migration? CEPS Papers in Liberty and Security in Europe(12). 